\title{
DIE ERDMAGNETISCHEN ELEMENTE IN TSINGTAU, CHINA.
}

Die nachstehenden erdmagnetischen Elemente sind die ersten Resultate der Beobachtungen mit dem kürzlich hier eingetroffenen Stationstheodolit von Tesdorpf. Obschon es sich nur um einige Tagesmittel handelt, an die eventuell noch kleine Korrektionen anzubringen sind, möchte ich die Daten doch umgehend veröffentlichen, da sie vielleicht schon Verwendung finden können. Für Anfang März rgI2 ist der Tageswert in:
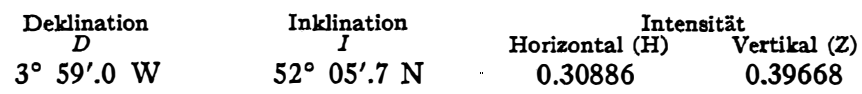

Im Oktober 1908 hat Herr Edmunds (Carnegie Institution of Washington) magnetische Beobachtungen in Tsingtau ausgeführt und dabei gefunden :

$\begin{array}{cccc}D & I & H & Z \\ 3^{\circ} 48^{\prime} .1 \mathrm{~W} & 52^{\circ} 21^{\prime} .5 \mathrm{~N} & 0.30766 & 0.39890\end{array}$

Das hiesige Instrument ist auf Potsdam bezogen, das von Herrn Edmunds jedenfalls auf Washington, die gegenseitigen Beziehungen sind mir jedoch zur Zeit nicht bekannt. Da die letzteren Beobachtungen zudem auf einem jetzt nicht mehr vorhandenen, jedenfalls aber nicht störungsfreien Backsteinpfeiler ausgeführt worden sind, lässt sich die jährliche Aenderung der Elemente nur unsicher aus den oben gegebenen Daten ableiten.

B. MEYERMANN.

Tsingtau, 1912, März 8.

\section{REQUEST FOR DATA.}

The undersigned respectfully requests that papers and not yet pubished observations of earth-magnetic and air-electric phenomena, purple light, halos, coronae, luminous night-clouds, aurora borealis and australis and zodiacal-light for June 30 to July I, 1908, September 25, 1909, and May I9, I9Io, be sent to him.

May 30, rgiz.

D. STENQUIST,

Frejgatan 69, Stockholm, Sweden. 